\title{
Ordinary days in paradise
}

Bob Webzell

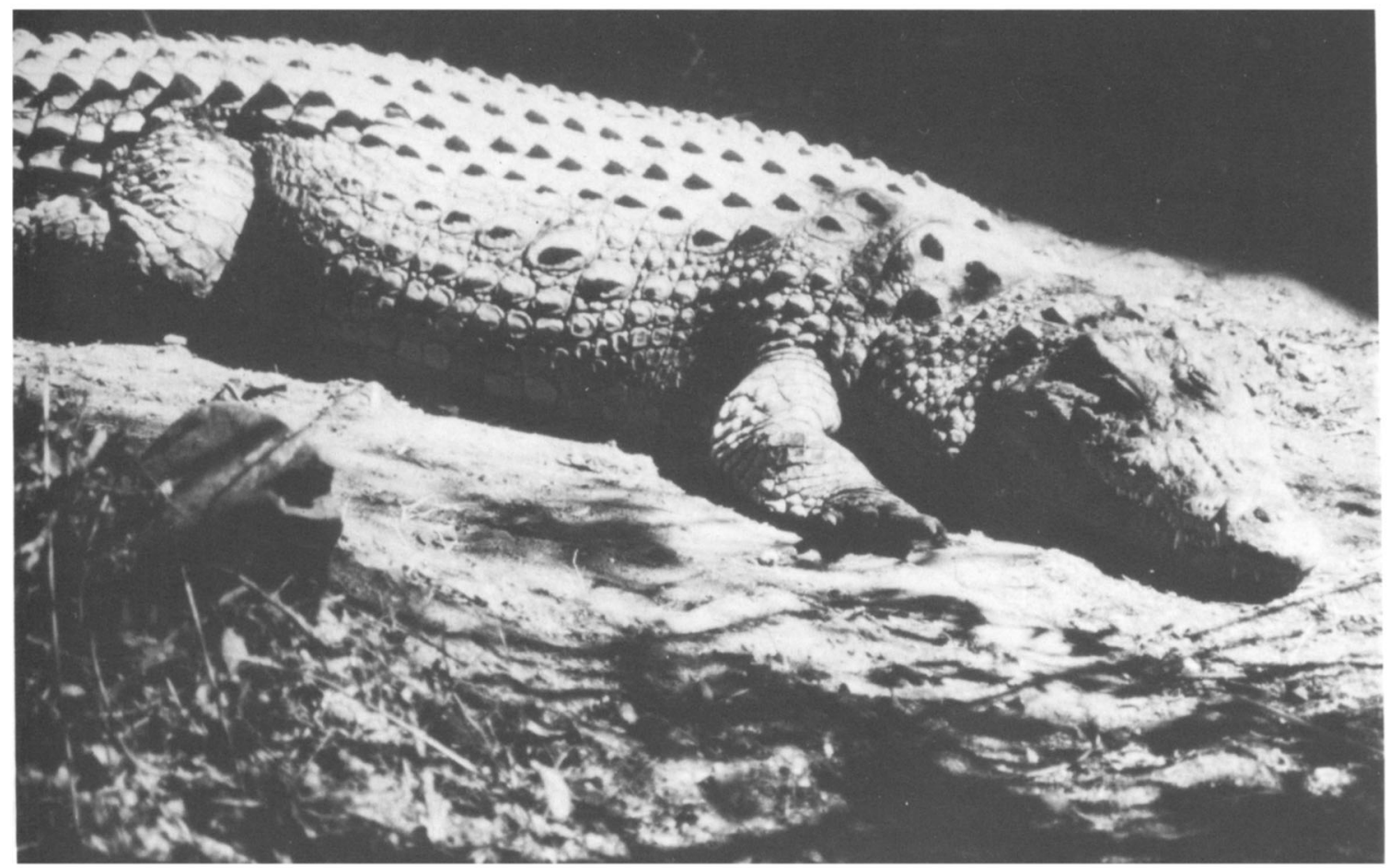

Basking crocodile (Bob Webzell).

In 1985 the University of Kent, with the FFPS, organized a study tour to the Luangwa Valley in Zambia. The author was among the participants and describes his once-in-a-lifetime experience.

I had long ago promised myself a visit to the great national parks of Africa. When the opportunity to join the University of Kent Study Tour to Zambia, led by Dr Ian Swingland, presented itself, I could not resist it.

I planned for the trip over many months, selecting the right lenses, film and photographic accessories for my camera, and reading Norman Carr and John Hanks, as well as literature and maps from the tour operators, Ecosafaris, and the Zambian Tourist Board. 178
On 20 July 1985, eight relative strangers met at Heathrow Airport and were greeted by Peter Moss, Director of Ecosafaris, who, in conjunction with Wilderness Trails, was to give us invaluable and efficient support throughout our 15-day tour. After a nine-hour overnight flight, I saw my first African dawn.

A one-hour internal flight took us from Lusaka to Mfuwe in the Luangwa Valley. Open-topped safari vehicles drove us the final $60 \mathrm{~km}$ along dirt roads to Chibembe. From our elevated position we caught our first tantalizing glimpses of the birds and mammals we had travelled so far to see; our Zambian driver stopped at every opportunity to allow us to gaze at zebra, elephant, impala and eagle.

Oryx Vol 20 No 3. July 1986 
The Luangwa Valley National Park is as large as Wales. It covers $15,500 \mathrm{sq} \mathrm{km}$ of the southern end of the Great Rift Valley and is composed principally of mopane woodland and bush, interspersed with areas of coarse grasses and herbs. The valley basin is wide and flat, and the Luangwa River and its many tributaries meander through it, constantly changing course. The resulting ox-bow lagoons provide numerous watering holes for game of all sizes and sanctuary for countless hippo, crocodile and waders.

The life-giving waters of the Luangwa also pose a major threat to this reserve, which has Africa's greatest concentration of wildlife. The southeastern park boundary is gazetted for hundreds of kilometres in terms of the Luangwa's water course. Changes in patterns of flow can be argued to redefine the boundary between game reserve and game management areas that surround the park, and legalized hunting, as much as tourism, brings much needed foreign currency into this developing country.

We were based at Chibembe Lodge, managed by Wilderness Trails, on the shady bank of the Luangwa River. It offered a unique combination of comfort, service and enchanting environment. While one breakfasted, with a choice of menus, impala, zebra, waterbuck, puku and baboon drank on the far bank not 50 metres away, and hippo wallowed in the murky waters in between.

July proved to be the Zambian winter, towards the end of the cool dry season. The skies were cloudless, temperatures were generally in the mid-seventies, and biting insects were almost non-existent. To make the most of the short tropical days, it soon seemed very natural to rise at $5 \mathrm{a} . \mathrm{m}$. and to go to bed to the sound of countless frogs and crickets by 9 p.m.

Our trail leader was lain MacDonald, a graduate teacher with an infectious enthusiasm and respect for this marvellous countryside; his local knowledge and game-detecting abilities were a constant source of wonder to us all and his practical skills linked superbly with Ian Swingland's theoretical knowledge.

Landcruiser safari vehicles were always available, and for approximately half of our 10 days in the Luangwa Valley we used these vehicles for game viewing or for night drives. From the safety of our Ordinary days in paradise vehicle, it was possible to get very close indeed to lion, elephant, giraffe and buffalo, and it permitted many splendid photographic and viewing opportunities. Afternoon and evenings presented further opportunities. Lion, unseen in the heat of the day, yawned and stretched, nuzzled each other in greeting, and set off to seek prey as darkness fell. Under the guidance of Norman Carr, whom we were fortunate to meet at Mfuwe Lodge one evening, we watched in awe as four hyena cubs emerged from their den to play in the twilight. We all sat, telephoto lenses poised, scared to be the first to press the shutter lest it sent them scampering out of sight. Someone eventually took the lead, the click of his shutter brought no reaction from the cubs; they even came closer as trigger fingers clicked ecstatically.

On our evening drives, we would rig up one or two spotlights on the landcruiser in order to spot nocturnal animals. We saw night-jars, owls, hares, mongoose, civet, genet and hyena, but leopard eluded us all. Nor did we see black rhino, but Dr Nigel Leader-Williams talked to us about his work with the 'Save the Rhino Trust', and his wife Alison discussed her research with puku on location near Chinzombo.

Our discussions ranged from termites and butterflies, scavengers and raptors, to antelope and carnivores, but we probably gave the elephant most attention. The elephant culling described by John Hanks in the late 1970s has regrettably been replaced by poaching, and the elephant population of 100,000 in 1980 is now probably as low as 40,000. However, the effect that the elephant has had upon areas of the park, especially upon the shallow-rooted trees of the mopane woodlands and the baobab trees, is all too obvious. Many areas of woodland have been reduced by elephant and by fire to open plains of grass or to lifeless expanses of sun-parched soil and dust. I took some comfort in the knowledge that cheetah, formerly believed to be extinct in this part of Africa, have recently been sighted in the newly formed grasslands, which ideally suit the speed and hunting techniques of this specialist.

The part of the tour that excited me most was the opportunity, unique to the Luangwa Valley, to undertake a walking safari. They were pioneered

179 


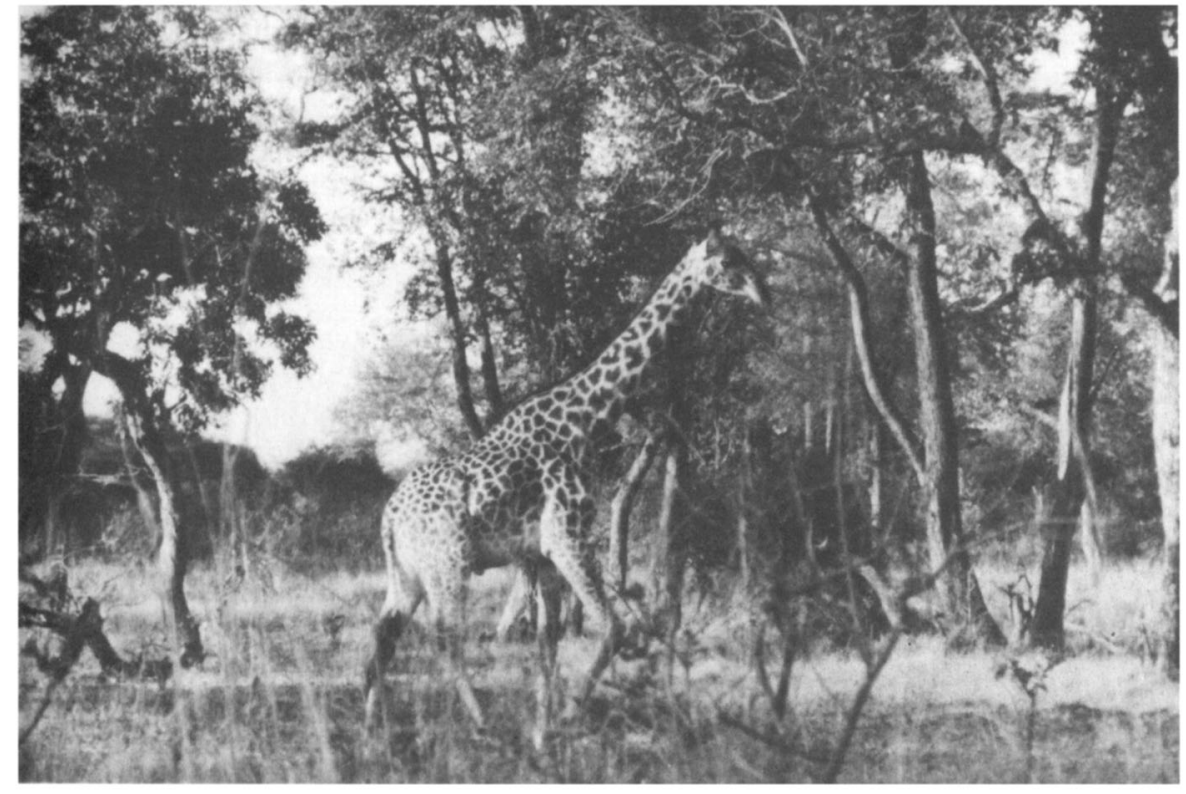

Thornicroft's giraffe (Bob Webzell). from this camp by Norman Carr in the 1950s. An evening briefing by lain MacDonald over drinks around a log fire had preceded our dawn call. We breakfasted, crossed the Luangwa, and began our four-and-a-half-day walking safari.

Preceded by our trained game guard, Patrick, and our trail leader, and backed up by Maxon, our all-important tea-carrier, we walked in orderly file and enjoyed the experiences of meeting and viewing game on foot. The animals were generally more cautious of humans on foot than of humans in vehicles, but would stand at a respectful distance and watch, as we did. On one occasion we came unexpectedly close to a buffalo, and on another to a cow elephant with a young calf. On both occasions the trail staff skilfully manouvered us to a place of safety where our presence could be acknowledged by, but not be threatening to, the animals. On foot there was time to study a termite mound, the spoor and pug marks of animals, feathers, porcupine quills, bones and teeth, aardvark burrows, weaver-bird nests, flowers and sausage trees. We spent two nights each at the trail camps at Mukhango and Kasensanya, sleeping beneath mosquito nets in rondavels made of grass and palm. We showered under the stars and dined by gas lamp. Roast meats, steam puddings and even two birthday 180 cakes were produced by the permanent Zambian staff, who were credits to their camps and to their professions.

The nights in the bush were equally rewarding. Close to Mukhango, a leopard twice invaded a troop of resting baboons, whose barks and cries filled the night air. Hippo left the water at night to graze, and we heard their satisfied snorts and chomping. At Kasensanya a lion roared close to our camp in the early hours. Moffat, the cook, insisted on taking us next morning to see the place where he claimed to have confronted the beast and driven it off into the night. Every sunrise and sunset was an experience I (and my camera) never wanted to miss. The colours were spectacular and the reflections in rivers irresistible.

Our safari walks were also rich in bird life. At lagoons we sat and watched heron, ibis, whistling duck, Egyptian geese, lily trotters, egret and stork. Glossy starling, kingfishers and woodpeckers, so much more common and colourful than their European cousins, were found on tree-lined river banks, and the calls of owls and hadada ibis enriched the sunsets. In two separate places we spotted the rare Pel's fishing owl, which returned our gaze for several minutes before flapping away on massive wings. Almost every glance at the sky revealed at least one eagle, often the bateleur,

Oryx Vol 20 No 3. July 1986 
Impala buck (Bob Webzell).

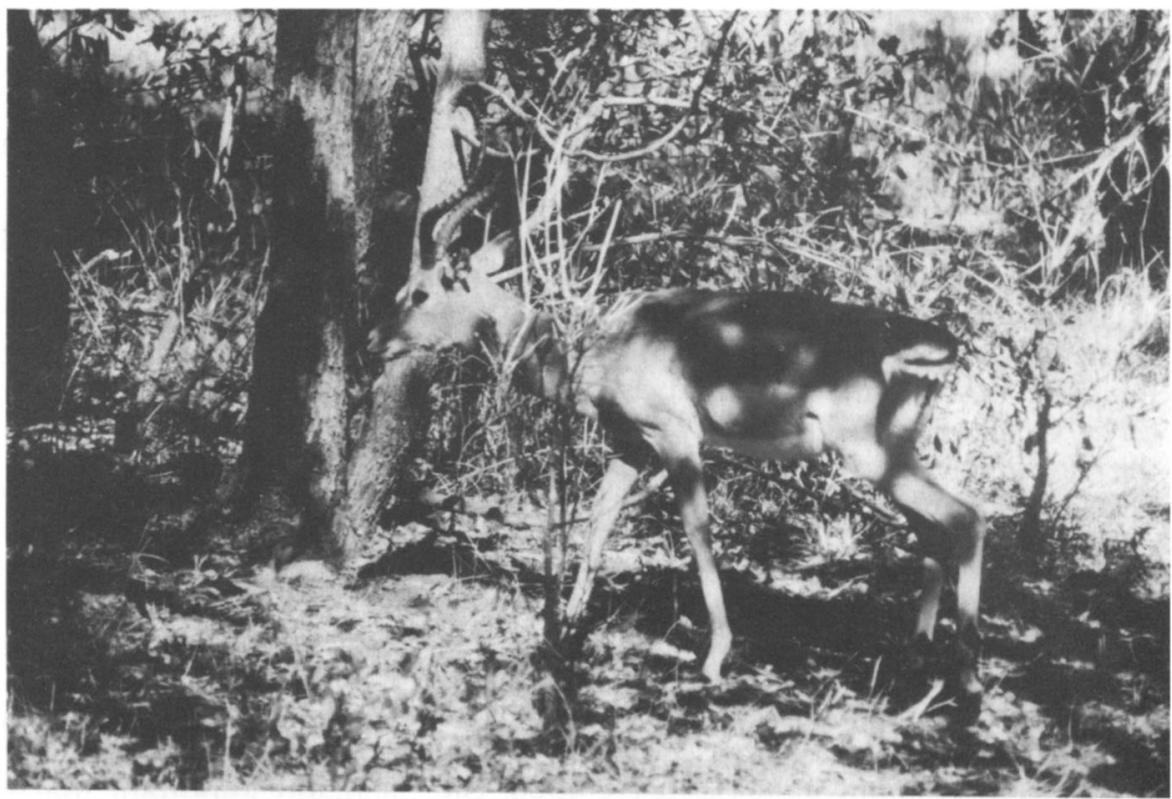

with its dramatic tumbling display. The piercing cries of fish eagles were music to our ears, but invoked alarm in colonies of nesting birds.

One morning while walking, we observed a hyena kill a young puku. A previously clear sky was soon thick with up to 50 circling vultures. We waited over an hour to see if they would descend to the kill, but our presence under a strangling fig tree was no secret to their powerful eyes and we finally decided to concede defeat and leave the kill to the hyena, the vultures and the insects.

Later, back at Chibembe, as we enthused about our many experiences over a local beer in the bar, a fellow trail leader interjected to suggest politely that ours had been "quite ordinary days here in paradise'. The generator flickered its warning of impending shutdown as eight weary and suntanned people retired to their beds, while Venus and the Southern Cross shone brightly above.

After 10 full days, we prepared for the final drive back to the airport at Mfuwe. In the visitors' book, which was filled with glowing superlatives from visitors from many nations, I simply wrote 'I'll be back'. Our tour, however, did not end there. Two internal flights took us to Livingstone for a view of the Victoria Falls. While the hotel in which we stayed for the next two nights was all one could wish for in accommodation, it was somehow an Ordinary days in paradise unwelcome jerk back into civilization after nearly a fortnight in the natural environment of Luangwa.

We crossed the border into Zimbabwe to view the falls from the Zimbabwe side and took a short minibus trip into the small and partially controlled Musi-au-Tunya National Park. It was here that I eventually saw the endangered white rhinoceros. A lone rhino grazed on sparse vegetation, apparently unconcerned by the vehicle with its load of excited passengers. There were other delights here: we were $1000 \mathrm{~km}$ from Luangwa Valley and 4 degrees further south, and we saw Cape giraffe instead of Zambia's Thornicroft's giraffe, and a different subspecies of baboon. Turaco, black hornbills, bulbuls and robinchats were all spotted in the rain forest, which prospered in the spray from the falls.

The tour was all I had hoped for in a once-in-alifetime holiday - and more. I went to Africa to see wild animals in their natural environment, and I achieved this, but I also made good friends, shared unforgettable experiences, and met in the Zambians a warm and friendly people who have led me to question my own values and expectations.

Bob Webzell. 30 The Foreland. Canterbury. Kent CT1 3NS. UK 